\title{
DEVELOPING CONTEXTUAL LESSON PLANNING TO ENGAGE STUDENTS' UNDERSTANDING IN THE ROLE OF GENDER IN LANGUAGE USED IN DAILY LIFE
}

\author{
TIARA RETNO HARYANI
}

tiara.03march@gmail.com

Universitas Islam Lamongan

\begin{abstract}
:
Language is not only simply a means of communicating information, but also means of establishing and maintaining relationship with other people (Trudgil, 2000). In social life, the first thing that you will notice is the gender of the person we met. It is a fundamental and obvious thing before we can have an interaction or communication with somebody else. The objective of the activity is to direct the students in understanding the role of gender in language for daily life more deeply. The students are expected to be able analyze the language phenomena in their daily life. The activity is started by explaining the materials to the students about gender role, gender bias, and gender dialect used. The second step is that grouping the students and asks them to discuss about the phenomena of gender in language used in their society so that they know how the characteristic of each gender in their society. The last step is discussing the results together in class. This activity is probably appropriate for the advanced learners, such as university students. It can gain the students' knowledge and raising the students' confident in stating their opinion in discussion.
\end{abstract}

Keywords: contextual, lesson planning, role of gender

\section{Introduction}

In our social life, we live and communicate with others by using appropriate language. Language is not only simply a means of communicating information, but also means of establishing and maintaining relationship with other people (Trudgil, 2000). In social life, the first thing that is very important to be noticed is the gender of the person we met. We may meet people from different area which have different characteristic, accent, dialect, and even language. However, the first thing that you will notice is the gender of the person we met. It is a fundamental and obvious thing before we can have an interaction or communication with somebody else. Sometimes, people may be irritated if we call them wrong in a conversation. If we misrecognize the gender of people we met and give wrong title or salutation her/him, it may put you in difficult situation, or event a terrible problem. The language used by particular gender is dissimilar. The differentiation of sex or gender exists and obvious in society all over the world. It may be used to determine the status, degree, hierarchy, or even to determine the language that must be used for the types of gender.

The relationship between language and gender has become an interesting topic within sociolinguistic and related 
discipline. According to Sunderland and Swann (2012), gender has been a social variable in quantitative studies of language variation carried out since 1960, a frequent finding being that, amongst speakers from similar social class background, women tend to use more standard or "prestige" language features and men more vernacular language features. It shows that women and men have different communication styles that distinct them in society.

The teaching of language and gender is widespread, at least across the "western" country, whether in the form of coherent modules on the topic, or as sessions in modules, or within nonlanguage programs. Though it is a very crucial issue, there is no a settled curriculum provided, particularly in Indonesia. It makes many gender bias phenomena occurred in society, especially in education field. Sometimes, sexist language can also be elicited because there is no settled subject discussed about it. Sexist language is language that expresses bias in favour of one sex and thus treats the other sex in a discriminatory manner (Lei, 2006). Sexist language is one of the gender bias occurred in the society. In avoiding this phenomenon, teacher should, at least, implicitly explain it to the students so that they can be more aware of it.

Hence, the aim of this paper is to introduce the phenomena of gender role, gender bias, and the dialect that usually applied of each gender. The students are expected to be more aware of the phenomena so that they can have gender equality in their daily life, especially in their education environment.

\section{The Topic}

In the past, women are supposed to stay at home, remaining powerless and generally subordinate to man, whereas men are considered as the centre both in the family and society. Hence, women became the "weaker gender" at that time since gender is both cultural and individual concept. According to Sunderland, gender characteristics are thus not just given, but rather socially constructed. That is why gender bias can influence the students' behaviour, point of view, and their language.

In education field, the practice of gender bias can be explicitly and implicitly occurred. For instance, it may be in the form of materials or pictures provided in the course book used at school, different methods in classroom activities and management related to gender, different assessment given for different gender of students, etc as it usually related to gender role and gender discrimination. For instance, have you once notice that people tend to point boys to be the leader or captain, and girls are usually be a secretary or treasurer in class? Well, you have witnessed the practice of gender stereotype or gender role in a small unit of education field. Some people say that boys can do more than girls in leading particular things. Yet, some people argue that girls also have the ability as well as boys do. Thus, we may find many females become leaders or have high position in western or other advance country, but not that often in developing countries.

According to Aoyagi, Suda, and Shinada (2011), gender roles are those behaviours, tasks and responsibilities that a society considers appropriate for men, women, boys and girls. Then, gender discrimination is any exclusion or restriction made on the basis of gender 
roles and relations that prevents a person from enjoying full human rights. The existence of these phenomena in school context can have a great influence toward the students in their daily life.

The objective of this teaching and learning activities is to direct the students in understanding the role of gender in language for daily life more deeply. The students are expected to be able analyze any gender language phenomena in their daily life, so that they are able to avoid the practice of gender bias, gender discrimination, and gender role in society, especially in education field. Moreover, the students may enlarge their knowledge about the gender problem phenomena, which is not very popular in Indonesia.

\section{Sample of The Teaching Procedures In The Lesson Plan}

Since the objective of this paper is to introduce the students about gender in language used in their daily life by using contextual lesson plan, there is a necessity to apply an appropriate approach in implementing the lesson plan. In order to understand the material deeply about the gender and language, the students are needed to be given Contextual Teaching and Learning (CTL). This approach emphasizes teacher's effort to relate teaching contents to students' environment, and to relate students' knowledge to its implication in real life (Fachrurrazy, 2010:46). Therefore, the lesson plan applied is more focused on the students' works and activities based on their contextual daily life.

The teaching procedure is quite simple, yet it can influence the students' point of view toward the phenomena occurred in their daily life. The teaching procedure covers the pre-teaching activities, whilst teaching, and post teaching activities.

Pre-Teaching

1. The teacher greets the students.

2. The teacher asks the students about the previous meeting materials

3. The teacher answers the students' questions about the previous materials (if any)

4. The teacher asks the students' background knowledge about gender problems phenomena.

\section{Whilst-Teaching}

1. The students are divided into groups of five students.

2. Each group of students is given a list of words and they are asked to categorize it according to gender (Task 1).

3. The teacher/lecturer starts discussing the answer of the task.

4. The teacher/lecturer explains the materials of gender dialect and gender bias to the students.

5. The students assigned to discuss the gender dialect used that they know and explain the characteristic of each term (Task 2).

6. The students are assigned to discuss about the phenomena occurred in their daily life related to gender bias and sexist language and give the example of each term (Task 3).

7. The teacher/lecturer collects the students' works.

8. The teacher/lecturer leads the discussion of the groups based on the answers they have submitted.

\section{Post-Teaching}

1. The teacher/lecturer asks to conclude the materials orally 
2. The teacher/lecturer gives the opportunity for the students to ask their difficulty in the lesson (if any).

\section{Conclusion}

In short, we can say that the study of gender is actually important for the students since they need to avoid the implementation of gender bias, gender role, and gender discrimination. Even though gender has not been in a settled curriculum, especially in elementary, junior high, and senior high school, they should at least know the phenomena happened in their daily life. By using CTL approach, the students are expected to be able to understand the material and can analyze it in contextual situation in their daily life. After the students understand the material, they should be more aware of the phenomena discussed since education field can also give a big influence toward the students' point view, behavior, and other aspects of their life.

\section{References}

Aoyagi, Midori, Eiko Suda, and Tomomi Shinada. 2011. Gender Inclusion in Climate Change Adaptation. ADBI Working Paper Series, (103): 1-19

Fachrurrazy. 2010. Teaching English as Foreign Language for teachers in Indonesia. Malang.

Lei, Xiaolan. 2006. Sexism in Language. Journal of Language and Linguistic, 5 (1): $1-8$.

Surnderland, Jane and Joan Swann. Teaching Language and Gender, (Online), (www.llas.ac.uk/resources/gpg/2827), accessed November $24^{\text {th }}, 2012$.
Trudgil, Peter. 2000. Sociolinguistics: $A n$ introduction to Language and Society. London: Penguin Books.

\section{Appendix}

\section{Task 1}

Read though the term below and sort them into two lists, according to whether you think the terms are more commonly used for women or men.

\begin{tabular}{|c|c|}
\hline $\begin{array}{l}\text { Dominant } \\
\text { - } \text { Independent } \\
\text { - Competitive } \\
\text { Beautiful } \\
\text { Physique } \\
\text { - Athletic } \\
\text { Pretty } \\
\text { - Chrturing } \\
\text { - Handsome } \\
\text { Well-built }\end{array}$ & $\begin{array}{l}\text { Emotional } \\
\text { Elegant } \\
\text { Ftrong } \\
\text { Fragile } \\
\text { Ambitious } \\
\text { Aggressive } \\
\text { Emphatic } \\
\text { - } \text { Mearfular } \\
\text { Slim } \\
\text { Heat } \\
\text { Hysterical }\end{array}$ \\
\hline
\end{tabular}

Task 2

Discuss the gender dialect used that you know and infer the characteristic of each gender.

a. Woman

b. Man

Task 3

Discuss the phenomena occurred in your daily life related to gender bias and sexist language and give the example of each term. 